\title{
Physico-Chemical Analysis and Social Impacts of Heavymetals from Landfill Leachates in Groundwater: A Case Study of Ogeese Community, Oyo State, Nigeria
}

\author{
Oluwatobi Idlowu Alawode ${ }^{1}$, Olumuyiwa Idowu $0 \mathrm{jo}^{2}$ and Oludamilare Bode Adewuyi ${ }^{3 *}$ \\ ${ }^{1}$ Department of Agricultural and Environmental Engineering, University of Ibadan, Nigeria \\ ${ }^{2}$ Department of Agricultural Engineering, Ladoke Akintola University of Technology, Nigeria \\ ${ }^{3}$ Department of Electrical Engineering, University of the Ryukyus, Japan
}

Submission: February 06, 2019; Published: February 25, 2019

*Corresponding author: Oludamilare Bode Adewuyi, Department of Electrical Engineering, University of the Ryukyus, 1 Senbaru, Nishiharacho, Nakagami, Okinawa, 903-0213, Japan

\begin{abstract}
Protecting the groundwater resources is very essential for environmental sustainability and improved quality of life in developing regions of the world; and non-biodegradable heavy metals in leachates due to indiscriminate solid wastes and landfills management is recognized as the main threat to groundwater quality in these regions. In this study, the physico-chemical constituents' determination and the health impacts assessment of soil and groundwater samples from six sites around a prominent uncontrolled landfill in the fast-growing Ogeese community of Oyo, southwest Nigeria, was conducted. The samples are analyzed for heavy metal components such as zinc, lead, copper, cadmium, manganese and iron using the Atomic Absorption Spectrometeric analysis and their concentration in each sample in $\mathrm{mg} / \mathrm{l}$ and $\mathrm{mg} / \mathrm{kg}$ for water and soil, respectively, are compared with the world health organization safe limits. The heavy metal concentration in most of the samples exceeds the WHO standard; hence there is a need for proper regulation and remediation action to improve the environmental and health standards of the inhabitants of this community and other similar communities.
\end{abstract}

Keywords: Heavy metals; Environment; Sustainability; Health impact; Atomic absorption spectrometer

\section{Introduction}

The problem of population explosion across the globe and the rate of urbanization in developing nations has led to the problem of congestion in major cities, water scarcity in arid regions and increased environmental pollution in the developing regions of the world [1,2]. Problems associated with waste generation as well as their disposals have become more pronounced and more debilitating especially in its handling. Land disposal has been from age long years the most common management strategy for municipal solid waste and most African cities have relied heavily on land disposal as a method by which generated solid waste can be catered for. Land filling is defined as the disposal, compression and embankment fill of waste at the appropriate site far from human interaction [3]. Ordinarily, land filling has been adopted by many communities because of its low cost but over time, due to the decrease in the availability of land for land filling; it has become much more expensive if not difficult to effectively practice land filling as a municipal waste disposal method.
Landfills in recent years have helped to contribute to minimize the risk associated with indiscriminate disposal of waste to public health and safety. As good as this management method sounds; it has however generated leachates that pose a major threat to the groundwater quality especially in areas around or close to the open dumpsite. Leachates from dumpsites or landfills are majorly as a result of liquid wastes disposed in the land fill or sometimes, the decom-position of solid waste which is aided by surface runoff in the case of erosion or precipitation [4]. It has been observed that the untreated chemical waste and the indiscriminate disposal of hazardous waste from industrial activities on municipal dumpsite can increase the level of toxic chemicals contained in the leachates produced from the wastes on the dumpsite.

The practice of land fill system as a method of waste disposal in many developing countries are usually far from standard recommendations, thereby, making landfills a major source of groundwater and soil pollution due to the production of leachates 
and its migration through the soil into the groundwater aquifers [5]. Water, due to its unique properties such as its polarity and hydrogen bonds makes dissolution, absorption, adsorption or suspension of many different Compounds easier, thus, water is not totally pure as it acquires contaminants from its surrounding and those arising from human and animal wastes as well as other biological activities [6]. From recent studies, it has been observed that the most common hazardous chemicals found in landfills leachates are heavy metals and different classes of organic compound such as phenols, halogenated hydrocarbons, plasticizers etc. most of these substances have been found to contain a high level of toxicity and could cause severe contamination problems upon exposure to the environment $[7,8]$. Water, due to its unique properties such as its polarity and hydrogen bonds, makes dissolution, absorption, adsorption or suspension of many different compounds easier. Thus, water is not totally pure as it acquires contaminants from its surrounding and those arising from human and animal wastes as well as other biological activities. Heavy metals are basically naturally occurring elements and could be present in the environment in varying concentrations. Certain Heavy metals such as $\mathrm{Ni}, \mathrm{Fe}$, $\mathrm{Zn}$, and $\mathrm{Cu}$ has been found to be of importance in the proper functioning of the ecosystem and their deficiency or excess could result into certain disorders as heavy metals has been understood to be the source of carcinogens to humans which could lead to various forms of life-threatening cancerous conditions due to bioaccumulation from consumption and exposure [9-11]. With these dangers of excessive bioaccumulation of hazardous heavy metals in our environment, there is the need to create awareness and to aid better understanding of the risk involved in the accumulation of heavy metals in the soil as well as their impact on the water quality that we consume.

Globally, there is a need to come to the awareness that our environment is a system and the responsibility of protecting it is not a regional issue neither is it a continental affair. It well goes beyond the local confines, but efforts must be started from somewhere while thinking globally. Thus, the purpose of this research is to directattention to the issues of effective management of the environment and the protection of water quality especially in areas where there is little or no awareness about the dangers inherent in the utilization of contaminated water and soil. Some of the key issues addressed in this work are:

a) the assessment of the level of toxicity of selected heavy metals present in the underground water samples taken from the wells around a dumpsite in a selected residential area;

b) to correlate the levels of the toxicity of the heavy metals present in the water samples with the leachates samples of the dumpsite to ascertain their source;

c) to relate the level of toxicity of these heavy metals in the samples collected with the permissible limits of some water quality standards such as WHO (World Health Organization).
Table 1: WHO standard for heavy metals in groundwater [12]

\begin{tabular}{|c|c|c|c|}
\hline S/N & Metal & $\begin{array}{c}\text { Highest De- } \\
\text { sirable Limit } \\
\text { mg/L }\end{array}$ & $\begin{array}{c}\text { Max. Permissi- } \\
\text { ble Limit mg/L }\end{array}$ \\
\hline 1 & $\mathrm{Fe}$ & 1 & 3 \\
\hline 2 & $\mathrm{Cu}$ & 0.5 & 2 \\
\hline 3 & $\mathrm{Zn}$ & 1 & 0.4 \\
\hline 4 & $\mathrm{~Pb}$ & 0.4 & 0.02 \\
\hline 5 & $\mathrm{Ni}$ & 0.01 & 0.05 \\
\hline 6 & $\mathrm{Cr}$ & 0.05 & 0.03 \\
\hline 7 & $\mathrm{Cd}$ & 0.003 & 0.01 \\
\hline 8 & $\mathrm{As}$ & 0.01 & 0.05 \\
\hline 9 & $\mathrm{Ba}$ & 0.05 & 0.001 \\
\hline 10 & $\mathrm{Sb}$ & 0.001 & 0.02 \\
\hline 11 & $\mathrm{Sn}$ & 0.01 & 1 \\
\hline 12 & $\mathrm{Se}$ & 0.01 & 0.4 \\
\hline 13 & $\mathrm{Mn}$ & 0.4 & \\
\hline
\end{tabular}

Table 1 [12] shows the WHO standard for heavy metal in Groundwater both at the maximum permissible limit and the highest desirable limit.

\section{Materials and Methods}

\section{Study area}

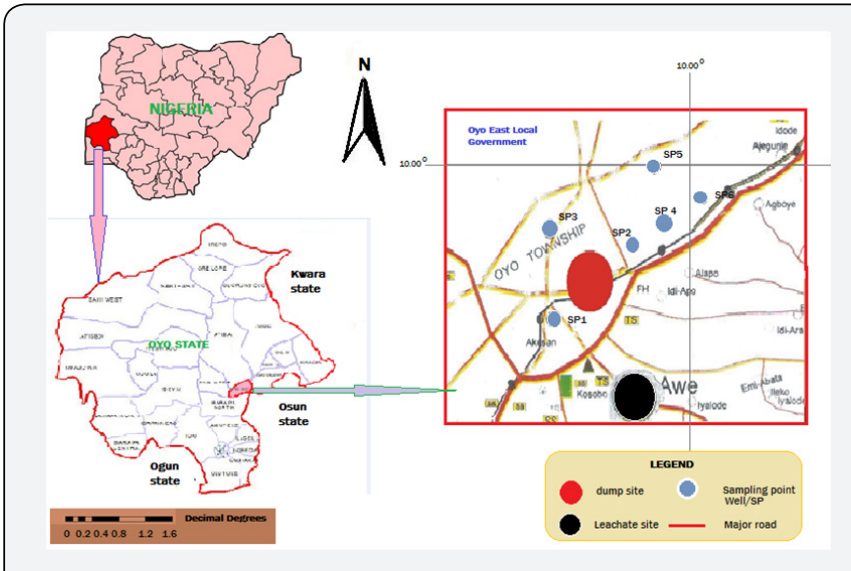

Figure 1: Location map of the study area.

This research work was carried out at the Ogeese community dumpsite in Oyo East Local Government, Oyo State, Nigeria. The community lies around latitude $8.00^{\circ} \mathrm{N}$ and longitude $4.00^{\circ} \mathrm{E}$ covering an approximate surface area of $2,427 \mathrm{~km} 2$ as shown on Figure 1. The geology of the town is characterized by the basement complex rocks which covers almost the total land surface area of the state. It lies in the humid tropical zone climate, having two seasons which are the dry and wet seasons. The study area is located around a dumpsite, shown in Figure 2, which is surrounded by majorly residential buildings, a mini marketplace, a filling station and a metal parts scrap center which contributes to the nature of waste being dumped on the dumpsite and the contributing leachates discharge. 


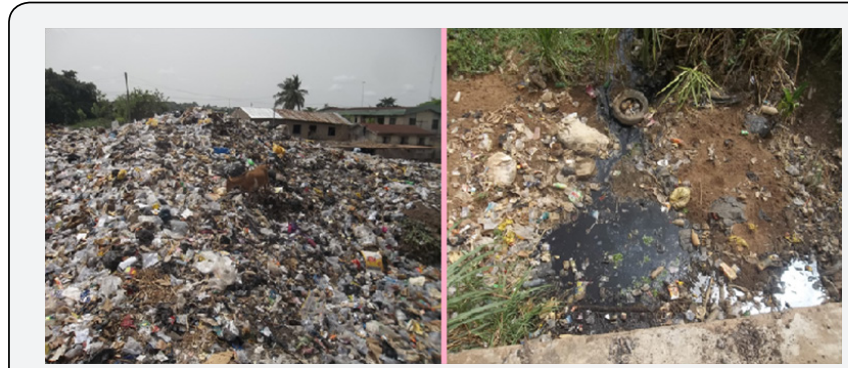

Figure 2: Image of the selected dumpsite and the nearby leachates.

Most of these residential buildings have no sewage disposal system; hence human waste and feces are deposited on this dumpsite alongside other industrial waste being carried from different parts of the town to be disposed at this particular dumpsite. Most of the hands dug well in this area are neither lined nor had a properly constructed base or cover. Some are simply covered with planks and rusted metal sheets as shown in Figure 3.

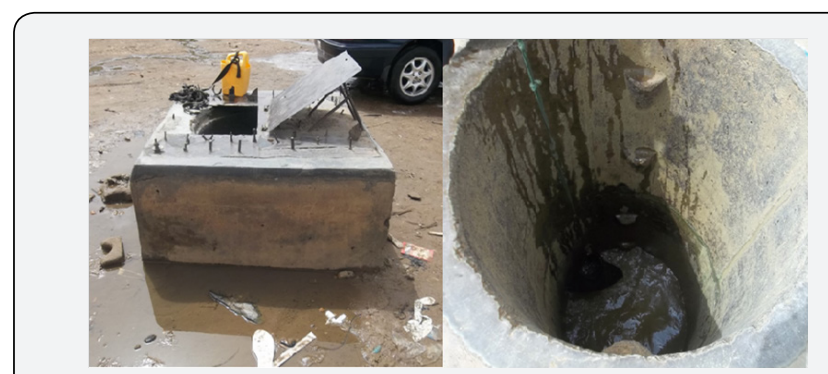

Figure 3: Image of some of the sampled dug wells near the dumpsite

\section{Sampling and pre-treatment}

In an effort to investigate the impact of the selected dumpsite and the surrounding leachates on the groundwater quality of the area where the dumpsite is situated, six samples of water were taken from six hand dug wells in the vicinity of the dumpsite. The water was collected in a $50 \mathrm{cl}$ bottles which have been cleaned and washed with distilled water. At the sampling points as well, the bottles were rinsed with the ground water to be sampled prior to filling and immediately the bottles were filled with the water to be sampled; $0.2 \mathrm{ml}$ of $\mathrm{HNO}_{3}$ was injected into the water samples for sterilization. This acidification of the water samples was done to keep the pH below 2 so as to preserve the heavy metal contents of the water samples and to reduce precipitation and microbial activities. The $\mathrm{pH}$ of the underground water samples was taken in situ and a volume of $100 \mathrm{ml}$ each of the underground water samples were concentrated with some drops of concentrated $\mathrm{HNO}_{3}$ to less than $50 \mathrm{ml}$ and made up to mark in $50 \mathrm{ml}$ standard ask for each sample. The concentrated extracts were kept at $4^{\circ} \mathrm{C}$ until spectrometric analysis is to be carried out.

About $1 \mathrm{~kg}$ each of six (6) composite soil samples from the soil surface within the vicinity of the sampled dug wells in the study area were collected in such a manner that it represented different part of the entire area. These samples were kept in a clean air tight polythene bag immediately after sampling and transported to the laboratory for further analysis. The soil samples were air dried and sieved with a $0.5 \mathrm{~mm}$ mesh size sieve. The $\mathrm{pH}$ of soil samples was determined by adopting the method by International Institute of Tropical Agriculture, Nigeria. The method involved taking the $\mathrm{pH}$ of $1: 1$ soil: deionized water extracts with a calibrated $\mathrm{pH}$ meter. This was carried out by accurately weighing $1 \mathrm{~g}$ each of dried and sieved soil samples $(0.5 \mathrm{~mm})$ into a series of acid washed beakers covered with wash glass; $30 \mathrm{ml}$ of $1: 1 \mathrm{HNO}_{3}$ : de-ionized water was added to each of the beakers containing the soil. They were each boiled gently on a hot plate in the hood while stirring intermittently until the volume reduced to about $5 \mathrm{ml}$. Exactly $10 \mathrm{ml}$ of $1: 1 \mathrm{HNO}_{3}$ : deionized water was again added, and the procedure was repeated. The second $5 \mathrm{ml}$ for each case were diluted appropriately with standard measuring flasks and preserved at $4^{\circ} \mathrm{C}$ before the Atomic absorption spectrometric (AAS) analysis. Blank solutions for all the analytes of interest were prepared and carried through the same experimental procedures as the samples in order to check reagent impurities and other interferences. The geographical details of the sampled sites are presented on Table 2.

Table 2: Geographical details of sampled sites.

\begin{tabular}{|c|c|c|c|}
\hline Site Type & $\begin{array}{l}\text { Distance from } \\
\text { Dumpsite (m) }\end{array}$ & $\begin{array}{l}\text { Sampling } \\
\text { Depth (ft.) }\end{array}$ & Coordinates \\
\hline Dumpsite & 15 & & $\begin{array}{c}(9.914 \mathrm{~N}, 8.095 \\
\mathrm{E})\end{array}$ \\
\hline Residential & 45 & $18(5 \mathrm{~m})$ & $\begin{array}{c}(10.328 \\
N, 9.206 \mathrm{E})\end{array}$ \\
\hline Residential & 124 & $90(27 \mathrm{~m})$ & $\begin{array}{c}(10.554 \\
N, 9.667 \mathrm{E})\end{array}$ \\
\hline Commercial & Approx.200 & $90(27 \mathrm{~m})$ & $\begin{array}{c}(11.213 \\
\mathrm{N}, 9.526 \mathrm{E})\end{array}$ \\
\hline Industrial & Approx. 480 & $92(28 \mathrm{~m})$ & $\begin{array}{c}(10.723 \\
N, 10.211 \mathrm{E})\end{array}$ \\
\hline Commercial & Approx.426 & $95(29 \mathrm{~m})$ & $\begin{array}{c}(10.865 \\
N, 10.176 \mathrm{E})\end{array}$ \\
\hline
\end{tabular}

Spectrophotometric measurement of heavy metal components

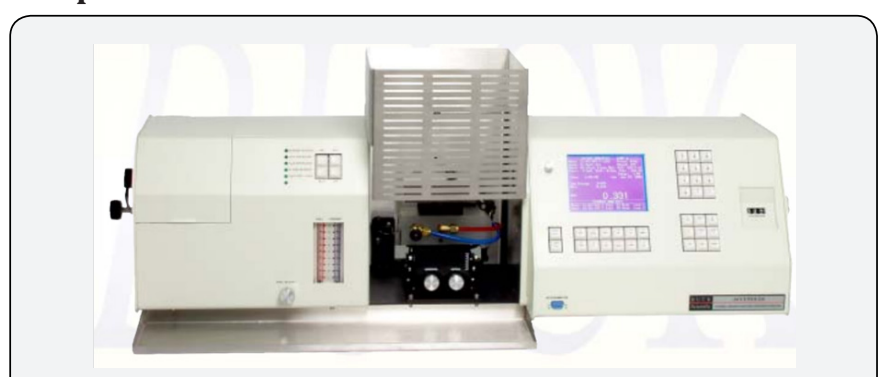

Figure 4: Buck Atomic Absorption Spectrometer (AAS) 210/211 VGP model.

For the purpose of this study, the analysis was carried out at the Department of Agronomy, University of Ibadan, Ibadan, Nigeria. The measurement and analysis of heavy metal concentrations such as $\mathrm{Pb}, \mathrm{Cd}, \mathrm{Mn}, \mathrm{Fe}, \mathrm{Cu}$ and $\mathrm{Zn}$ of the groundwater samples were determined using the Buck Atomic 
Absorption Spectrometer (AAS) 210/211 VGP model shown in Figure 4. The corresponding wavelength of each constituent heavy metals were directly measured on the machine for identification purposes. The principle involves the atomization of all samples by thermal sources and the absorption of a specific wavelength by the atomic source as it is being excited. The radiation used is a hollow cathode lamp containing as its cathode, the same element to be analyzed. The selected sample was then shaken vigorously after which $200 \mathrm{ml}$ was measured into a clean beaker. $4 \mathrm{ml}$ of concentrated nitric acid was then added and the resulting solution was evaporated to about $1020 \mathrm{ml}$. The solution was then filtered into a $25 \mathrm{ml}$ volumetric flask. The quantity of the same element absorbed by the atomic vapor is proportional to the concentration of the atoms in the ground state.

The concentration of heavy metals in the digested samples was then determined accordingly:

$$
\text { Metal Concentration, }(m g / l)=\frac{A \times B}{C}
$$

Where;

$\mathrm{A}=$ concentration of metal (instrument reading) in the digested solution (mg/L)

$\mathrm{B}=$ final volume of digested solution after making up to the mark (25ml)

C = initial volume of the sample taken $(200 \mathrm{ml})$.

\section{Results and Discussion}

\section{Wavelength of considered analyzed metals}

Each of the constituent heavy metals to be analyzed were identified on the Atomic Absorption Spectrometer with a corresponding wavelength shown in Table 3.

Table 3: Wavelength of each of the metals as read from the AAS machine.

\begin{tabular}{|c|c|}
\hline Metals & Wavelength \\
\hline $\mathrm{Zn}$ & 213.9 \\
\hline $\mathrm{Pb}$ & 283.3 \\
\hline $\mathrm{Fe}$ & 248.3 \\
\hline $\mathrm{Mn}$ & 279.5 \\
\hline $\mathrm{Cd}$ & 228.9 \\
\hline $\mathrm{Cu}$ & 327.4 \\
\hline
\end{tabular}

\section{Results from the groundwater samples analysis}

The summary of the results for the heavy metal concentration in the groundwater samples collected at different distances from the dumpsite is shown in Table 4. The result of the analysis showed the presence of potentially toxic metals in the water samples and there is no clear trend in the way the values vary from well to well. The result from the analysis is viewed in line with the WHO standard for heavy metal in ground water and it shows that the concentrations of some of the metals analyzed fall below the desirable standard while about three of the metals ranges above the set standard and one of the metals is just within the stipulated range set by the WHO standards. $\mathrm{Pb}, \mathrm{Cd}$, and $\mathrm{Zn}$ falls below the highest desirable limit while $\mathrm{Mn}, \mathrm{Cu}$ and Fe are relatively high at SP1 having a distance from dumpsite is $15 \mathrm{~m}$. At SP2 with a distance from dumpsite $45 \mathrm{~m}$ shows that all the parameters detected are relatively low except $\mathrm{Cu}$. Meanwhile at SP3 (145m to dumpsite), $\mathrm{Pb}, \mathrm{Cd}, \mathrm{Mn}$ and $\mathrm{Zn}$ are relatively low while $\mathrm{Fe}$ and $\mathrm{Cu}$ are relatively high compared to the HDL as shown in Table 1. Analysis for SP4 ( $221 \mathrm{~m}$ to dumpsite) shows that $\mathrm{Pb}, \mathrm{Mn}, \mathrm{Fe}$, and $\mathrm{Zn}$ are relatively low compared to HDL of the WHO standard while $\mathrm{Cd}$ and $\mathrm{Cu}$ are relatively high. SP5 (480m to dumpsite) shows that Cd, Mn, Fe and $\mathrm{Zn}$ are relatively low while $\mathrm{Pb}$ and $\mathrm{Cu}$ are relatively high compared to the HDL. SP6 having a distance of $426 \mathrm{~m}$ to the dumpsite shows that $\mathrm{Cd}, \mathrm{Mn}$, and $\mathrm{Zn}$ are relatively low while $\mathrm{Pb}, \mathrm{Fe}$, and $\mathrm{Cu}$ are relatively high. Thus, it is observed that the presence of $\mathrm{Cu}$ in the samples obtained is relatively high all through the Groundwater samples collected.

Table 4: Heavy metal ion concentration in $\mathrm{mg} / \mathrm{l}$ in the ground water samples.

\begin{tabular}{|c|c|c|c|c|c|c|}
\hline $\begin{array}{c}\text { Sample } \\
\text { Codes }\end{array}$ & $\begin{array}{c}\mathbf{P b} \\
(\mathbf{m g} / \mathbf{l})\end{array}$ & $\begin{array}{c}\mathbf{C d} \\
(\mathbf{m g} / \mathbf{l})\end{array}$ & $\begin{array}{c}\mathbf{M n} \\
(\mathbf{m g} / \mathbf{l})\end{array}$ & $\begin{array}{c}\mathbf{F e} \\
(\mathbf{m g} / \mathbf{l})\end{array}$ & $\begin{array}{c}\mathbf{C u} \\
(\mathbf{m g} / \mathbf{l})\end{array}$ & $\begin{array}{c}\mathbf{Z n} \\
(\mathbf{m g} / \mathbf{l})\end{array}$ \\
\hline SP1 & 0.235 & 0.001 & 6.61 & 13.9 & 0.841 & 0.004 \\
\hline SP2 & 0.187 & 0.001 & 0.03 & 0.53 & 0.811 & 0.004 \\
\hline SP3 & 0.031 & 0.001 & 0.27 & 2.5 & 0.847 & 0.043 \\
\hline SP4 & 0.14 & 0.007 & 0.04 & 0.59 & 0.817 & 0.001 \\
\hline SP5 & 0.445 & 0.001 & 0.08 & 0.35 & 0.793 & 0.004 \\
\hline SP6 & 0.408 & 0.001 & 0.26 & 1.23 & 0.825 & 0.003 \\
\hline
\end{tabular}

\section{Results from the soil samples analysis}

Table 5: Heavy metal ion concentration in $\mathrm{mg} / \mathrm{kg}$ in the soil samples.

\begin{tabular}{|c|c|c|c|c|c|c|}
\hline $\begin{array}{c}\text { Sam- } \\
\text { ple } \\
\text { Codes }\end{array}$ & $\begin{array}{c}\mathrm{Pb} \\
(\mathrm{mg} / \\
\mathrm{kg})\end{array}$ & $\begin{array}{c}\text { Cd } \\
(\mathrm{mg} / \\
\mathrm{kg})\end{array}$ & $\begin{array}{l}\text { Mn } \\
(\mathrm{mg} / \\
\mathrm{kg})\end{array}$ & $\begin{array}{c}\text { Fe (mg/ } \\
\text { kg) }\end{array}$ & $\begin{array}{c}\mathrm{Cu} \\
(\mathrm{mg} / \\
\mathrm{kg})\end{array}$ & $\begin{array}{c}\text { Zn (mg/ } \\
\text { kg) }\end{array}$ \\
\hline SP1 & 3.4 & 0.25 & 335.5 & 23700 & 39.4 & 152.5 \\
\hline SP2 & 415 & 17 & 1220 & 109000 & 2112.5 & 50.95 \\
\hline SP3 & 56.2 & 0.7 & 511 & 22825 & 47.6 & 127 \\
\hline SP4 & 34.15 & 0.95 & 182 & 12625 & 20.5 & 56 \\
\hline SP5 & 557 & 31.95 & 1010 & 232500 & 2062.5 & 5577.5 \\
\hline SP6 & 1330 & 11.95 & 1280 & 290500 & 3045 & 6107.5 \\
\hline $\begin{array}{l}\text { Aver- } \\
\text { age }\end{array}$ & 399.29 & 10.47 & 756.42 & 115191.7 & 1221.25 & 2011.91 \\
\hline
\end{tabular}

The summary of the results for the heavy metal concentration in the soil samples collected at different locations on the dumpsite is shown in Table 5. The result of the analysis showed the presence of potentially toxic metals in the soil samples and there is no clear trend in the way the values vary from location to location. It is observed from table 5 that there is a clear increase of heavy metals in sludge and soil/sludge mixtures for all tested elements except $\mathrm{Mn} . \mathrm{Zn}, \mathrm{Pb}, \mathrm{Cd}, \mathrm{Fe}$ and $\mathrm{Cu}$ have reached extremely high concentration in each of these samples compared to $300 \mathrm{mg} / \mathrm{kg}$ for $\mathrm{Zn}, 100 \mathrm{mg} / \mathrm{kg}$ for $\mathrm{Pb}, 3 \mathrm{mg} / \mathrm{kg}$ for $\mathrm{Cd}$ and $100 \mathrm{mg} / \mathrm{kg}$ for Fe of WHO maximum allowable heavy metals in soil. 


\section{Social and health implications on the residents}

From the result presented in the table above, at different distances from the dumpsite, the concentration of each of the heavy metals was determined. The metals analyzed in the water samples taken to the laboratory include cop-per, zinc, cadmium, lead, manganese and iron and the result is compared with the standard set by the World Health Organization (WHO) for heavy metal in groundwater quality as presented in table 1 . Values obtained for copper ranges from $0.793 \mathrm{mg} / \mathrm{l}$ to $0.847 \mathrm{mg} / \mathrm{l}$, which is above the highest desirable limit of $0.5 \mathrm{mg} / \mathrm{l}$ for World Health Organization standard but below the maximum permissible limit. Copper enters into water bodies mostly by anthropogenic activities like metal plating; industrial and domestic waste, mining, and mineral leaching. The high concentration of copper in the ground water samples of the dumpsite vicinity is contributing to rendering the water unfit for consumption. High concentration of copper in groundwater causes the following health disorders on ingestion and exposure such as experiencing nausea, vomiting, stomach cramps and it has been reported to cause liver and kidney damage and even death. The result for zinc shows that the values obtained for the wells ranges from $0.004 \mathrm{mg} / \mathrm{l}$ to $0.006 \mathrm{mg} / \mathrm{l}$ which is far below the desirable limits set by World Health Organization (WHO). The groundwater quality standard of zinc desirable limit is $1.0 \mathrm{mg} / \mathrm{l}$ and the maximum permissible limit for zinc in ground water quality is $3.0 \mathrm{mg} / \mathrm{l}$. None of the sampled well exceeds the desirable limit not to talk of the maximum permissible limit. Cadmium (Cd) concentration ranges from $0.001 \mathrm{mg} / \mathrm{l}$ to $0.007 \mathrm{mg} / \mathrm{l}$. This is below the desirable limit for World Health Organization. Cadmium is natural usually minor constituent of surface and ground water. The results also revealed that the concentration of lead in the study area ranges from $0.031 \mathrm{mg} / \mathrm{l}$ to $0.44 \mathrm{mg} / \mathrm{l}$ which is just suitable for the WHO limit of heavy metal in groundwater quality which is $0.4 \mathrm{mg} / \mathrm{l}$.

Lead is a very toxic element, which accumulates in the skeletal structure of man and animal. Manganese (Mn) concentration levels ranges between $0.03 \mathrm{mg} / \mathrm{l}$ to $6.61 \mathrm{mg} / \mathrm{l}$. The concentration is far above the desirable of $0.4 \mathrm{mg} / \mathrm{l}$ and maximum permissible limit of $0.4 \mathrm{mg} / \mathrm{l}$ at the well very close to the dumpsite and very low in well farther away from the dumpsite. Manganese impacts a bitter taste to water, it also lead to the coloration of the groundwater which is noticed in some of the wells (especially the first well near the dumpsite) selected for sampling. It stains cloths when used for washing and precipitate in foods when used for cooking and it also promotes the growth of algae in reservoirs. Wells with a fairly high amount of manganese in the study area indicates a level of pollution in these wells due to the effects of dissolved solids from the dumpsite. The Iron concentration in the study area ranges between $0.44 \mathrm{mg} / \mathrm{l}-3.90 \mathrm{mg} / \mathrm{l}$. the iron concentration in the well sampled very close to the dumpsite was dis-covered from the result of the analysis to be very high. This may be as a result of the downward leaching of the dumpsites dissolved solids into the well. Excess concentration of iron has a negative effect on the ground water quality of the dug wells in the area and on the health of the population consuming the ground water in the dumpsite vicinity as it can cause gastrointestinal irritation and enhance the growth of iron bacteria that affects the water taste. The high concentration values of iron have the potential of staining laundry, metal pipes for reticulation and scaling in pipes. It may also give undesirable taste. This explains the reddish-brown color stain commonly seen on most metal tanks and fence within the study area. Iron can be treated by encouraging the iron to precipitate when the water is exposed to the air. The study reveals that heavy metal concentration in the soil samples in the sampled area is above the desirable limit of WHO standards in some of the locations sampled and were considered un $\mathrm{t}$ for human consumption. And the results obtained from the soil sample con rms that obtained from the groundwater analysis. However, heavy metal concentrations such as that of lead $(\mathrm{Pb})$ is still within the maxi-mum permissible limit set by the WHO standard. In comparison with the WHO standard for heavy metal concentration in water, it could be inferred that the concentrations of $\mathrm{Cu}, \mathrm{Mn}, \mathrm{Pb}$ and $\mathrm{Fe}$, are far above the standard of WHO for heavy metals in most of the water samples taken from the well while $\mathrm{Cd}$ and $\mathrm{Zn}$ ranges below the desirable limits of World Health Organization (WHO). It can be inferred from the study that sludge of wastewater constitutes potential source of heavy metals contamination. Hence may constitute an environmental and health challenges in the long-term.

\section{Conclusion}

Variations in heavy metal concentrations in water and soil are consequences of a wide range of human activities which ranges from indiscriminate waste disposals to improper handling of water sources. In all the heavy metals tested for in this study, cadmium and lead are found to be the most common sources of air pollution. This is mainly result of various industrial activities been carried out in the area of study. Extensive sampling is necessary to include other study areas, and further research concerning contamination of plants grown beside dumpsites needs to be done. Provision of incinerators at specific points far from groundwater sources should be encouraged within the community and it is to be ensured that the incineration processes should be adequately monitored and Public enlightenment campaign on the effect of contaminated water and the danger of siting shallow wells close to dumpsites is to be embarked upon by the government and the media (print and electronic), schools, religious bodies.

\section{Acknowledgment}

The authors wish to acknowledge the support of the staff of the Department of Botany, University of Ibadan and the International Institute of Tropical Agriculture, Ibadan, Nigeria.

\section{References}

1. Scruggs C, Thomson BM (2017) Opportunities and challenges for direct potable water reuse in arid inland communities. Journal of Water Resources Plan-ning and Management 143(10).

2. Rashid M, Manzoor M, Mukhtar S (2018) Urbanization and its effects on water resources: An exploratory analysis, Asian Journal of Water, Environment and Pollution 15(1): 67-74. 
3. El-Salam MMA, Abu-Zuid GI (2015) Impact of landfill leachate on the groundwater quality: A case study in egypt. Journal of Advanced Research 6(4): 579-586.

4. Brennan RB, Healy MG, Morrison L, Hynes S, Norton D, et al. (2016) Management of landfill leachate: The legacy of european union directives. Waste Manag 55: 355-363

5. Mor S, Negi P, Khaiwal R (2018) Assessment of groundwater pollution by land lls in india using leachate pollution index and estimation of error. Environmental Nanotechnology, Monitoring Management 10: 467- 476.

6. Hasan M, Razoanul M, Khan I, Nesha MK, Akter Happy M (2014) Analysis of water quality using chemical parameters and metal status of balu river at dhaka, Bangladesh. Open Journal of Water Pollution and Treatment $1(2)$

7. Naveen BP, Mahapatra DM, Sitharam TG, Sivapullaiah PV, Ramachandra TV (2017) Physico-chemical and biological characterization of urban municipal landfill leachate. Environ Pollut 220(Pt A): 1-12.
8. Al-Wabel M, Yehya WA, AL-Farraj A, El-Maghraby S (2011) Characteristics of landfill leachates and bio-solids of municipal solid waste (msw) in riyadh city, saudi arabia. Journal of the Saudi Society of Agricultural Sciences 10(2): 65-70.

9. Liu L, Luo XB, Ding L, Luo SL (2019) 4 - Application of nanotechnology in the removal of heavy metal from water. In: Luo X, Deng F, (Eds.), Nanomaterials for the Removal of Pollutants and Resource Reutilization, Micro and Nano Technologies. Elsevier, USA, pp. 83-147.

10. Cai LM, Wang QS, Luo J, Chen LG, Zhu RL, et al. (2019) Heavy metal contamination and health risk assess-ment for children near a large cu-smelter in central china. Sci Total Environ 650(Pt 1): 725-733.

11. Edokpayi JN, Enitan AM, Mutileni N, Odiyo JO (2018) Evaluation of water quality and human risk assessment due to heavy metals in groundwater around muledane area of vhembe district, limpopo province, South Africa. Chem Cent J 12(1): 2.

12. (2017) World Health Organization, Guidelines for drinking-water quality, $4^{\text {th }}$ edition, incorporating the 1 st addendum.

Your next submission with Juniper Publishers will reach you the below assets

- Quality Editorial service

- Swift Peer Review

- Reprints availability

- E-prints Service

- Manuscript Podcast for convenient understanding

- Global attainment for your research

- Manuscript accessibility in different formats

( Pdf, E-pub, Full Text, Audio)

- Unceasing customer service

Track the below URL for one-step submission https://juniperpublishers.com/online-submission.php 